Original Article

\title{
EXTRACTION, ISOLATION OF ACTIVE PRINCIPLES, ANTI-BACTERIAL AND WOUND HEALING ACTIVITY OF THE MARINE ALGAL SPECIES OEDOGONIUM GLOBOSUM AND OEDOGONIUM INTERMEDIUM
}

\author{
KARPAKAVALLI MEENAKSHISUNDARAM ${ }^{1}{ }^{*}$, PRAKASH GOVINDARAJ ${ }^{2}$, SIVASUBRAMANIAM P. ${ }^{3}$, RANJITHKUMAR \\ DHANARAJ ${ }^{4}$, MOHAN SELLAPPAN 5
}

${ }^{* 1,2,3}$ Department of Pharmaceutical Chemistry, Karpagam College of Pharmacy, Coimbatore 641032 Tamil Nadu, India, ${ }^{4}$ Department of Pharmaceutical Analysis, Prime College of Pharmacy, Erattayal, Palakkad 678551 Kerala, India, ${ }^{5}$ Department of Pharmaceutical Biotechnology, Karpagam College of Pharmacy, Coimbatore 641032, Tamil Nadu, India Email: sreemenakag@gmail.com

Received: 17 Oct 2020, Revised and Accepted: 01 Apr 2021

ABSTRACT

Objective: Algae is the undisputed treasures of the sea and are a valuable raw material, providing unlimited opportunities for new drug discoveries. Marine algal products are in demand in the international market in the form of standardized algal extracts or semi-finished products.

Methods: Aqueous and methanolic extracts of Oedogonium globosum and Oedogonium intermedium species were obtained maceration and hot percolation. The active principles from 0 . intermedium were isolated, purified by column chromatography, and characterized by spectral studies IR, $\lambda$ max, ${ }^{1}$ HNMR and MS. The extracts of Oedogonium species were screened for their anti-microbial effects, acute dermal irritation and wound-healing activity studies.

Results: Comparing to Oedogonium intermedium (45 \%, 90 \%, 87 \%), very low extractive yields were obtained for Oedogonium globosum (10.80 \%, $37 \%, 28 \%$ ). At phytochemical screening, Terpenoids, Flavanoids and, Glycans were found to be present in a significant amount and upon their isolation, it was found that a collection of fractions from cold extract with Rf value in the range 0.32-0.34 as Glycans and those from the hot extract with $0.40-0.72$ as Flavanoids and those from methanolic extracts with $0.23,0.44$ and 0.71 as for Terpenoids. Anti-bacterial study revealed out the fact of Oedogonium species could give higher inhibition to gram-positive than for gram-negative bacteria at (10 $\mu \mathrm{g} / 10 \mu \mathrm{l} / \mathrm{disc}) \mathrm{concentration}$. No symptoms of systemic toxicity and mortality were observed. Silver sulfadiazine, more potent in wound closure, the effect of methanolic extracts of O. intermedium (87 \%) was almost at par to the standard (95\%) in action and significantly greater than 0. globosum (72 \%, P<0.05).

Conclusion: Admittedly, Oedogonium type algal species can be known as medicinal algae with a plethora of a wide range of pharmacological activities. Thus, this research work may be considered further for extensive innovative discoveries of new lead molecules and any other pharmacological activities, in the future.

Keywords: Oedogonium Globosum, Oedogonium Intermedium, Extraction, Phytochemical analysis, Isolation, Dermal irritation test, Anti-microbial and Wound healing Activities

(C) 2021 The Authors. Published by Innovare Academic Sciences Pvt Ltd. This is an open access article under the CC BY license (https://creativecommons.org/licenses/by/4.0/)

DOI: https://dx.doi.org/10.22159/ijpps.2021v13i5.40026. Journal homepage: https://innovareacademics.in/journals/index.php/ijpps.

\section{INTRODUCTION}

Nowadays, esteemed researches involve the transformation of these sponges into rich value biomass co-products in the pharma, nutrition, topical, cosmetic and greenery fields, livestocks, and organic fertilizers also, $50 \%$ of all oxygen production is by these invaluable species [1]. Within three years, i.e. from 2014-17, the growth of the market price of seaweed production has increased from 7000 tons to 16 million tons [2].

From the literature, the marine sponges do contain many chemicals viz., terpenes, sesquiterpenes, terpenoids and steroids, polysaccharides, essential amino acid, vitamins, minerals, cyclic-and peptides, proteins, alkaloids, tannins and phlorotannins, lipids, fatty acids, nucleic acid bases, ribonucleic acid (RNA), de-oxyribo nucleic acid (DNA), macrolides, polyketides [3-5]. It's a good source of minerals, vitamins, proteins, carbohydrates, and fibers [6, 7]. The proficient biological activities of algae from ancient times to a modern era include antidiabetic, anticancer [8, 9], antivirals, antimicrobials, anti-inflammatory [10], antioxidant [11], anticoagulants, antibiotics [12], antihypertensive agents, blood cholesterol reducers, dilatory agents [13], insecticides and antitumorigenic agents [14], nutritional supplement, for increasing skin thickness and elasticity beauty enhancers, growth factor modulators and other industrial purposes.

Since Phyto-constituents are multicomponent mixtures, their purification and determination are still very difficult. Wound closure property is incomparable in herbals and marine seaweeds and that may be by the enhanced formation of granulated tissues, collagen, skin appendages, and re-epithelialization [17]. On all the above background literature studies and analyses, in this paper, we are more interested to report first about its extraction results, microbicidal and wound ameliorating effects of the methanolic and aqueous extracts of Oedogonium globosum and Oedogonium intermedium and secondly on the isolation and characterization of active principles from Oedogonium intermedium.

\section{MATERIALS AND METHODS}

The chemicals and reagents used for the study, were of analytical grade and were procured from E-Merck. In this research project, some of the instruments viz., Schimadzu UV spectrophotometer (Model No. UV-2400PC) for UV spectral study, PC-FTIR equipment (Make: Schimadzu 8201) for IR spectral study and a Bruker 400 machine for ${ }^{1}$ HNMR and ${ }^{13}$ CNMR spectra were made used of.

\section{Collection and authentication of plant material}

Two freshwater seaweed samples were collected from local and in and around the regions of our institution, i.e. Othakalmandapam, Malumichampatti and Kinathukkadavu, Coimbatore, Tamil Nadu, during the low tidal conditions at a depth of 1-3 m. Undesirable matter viz., epiphytes, extraneous matter, and necrotic parts of the collected samples were removed. Algal samples with enough 
quantity were cleaned subsequently with tap-, fresh-and sterile distilled water, let the shade dried, chopped and crushed into a powder form in a mortar and pestle. Herbarium sheet was prepared and the taxonomic position of the same was identified by BSI, Southern Regional Centre, TNAU Campus, Coimbatore (BSI/SRC/
05/23/2017/Tech./3620 dated 29.03.2017). This report stated the scientific classification of the selected algae as Plantae kingdom; Chlorophyta division; Chlorophyceae class; Oedogoniales order; Oedogoniaceae family; Oedogonium genus and Globosum and Intermedium species.

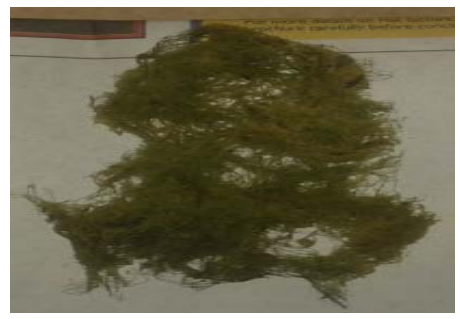

Oedogonium globosum

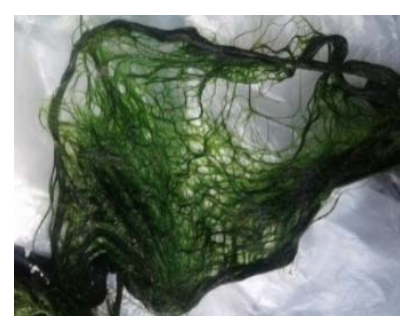

Oedogonium intermedium

Fig. 1: Oedogonium globosum and Oedogonium intermedium

\section{Extractions}

Algal extracts were prepared by maceration and hot extraction method. After drying the leaves of both algae (1 Kg each) in the working lab for $1 \mathrm{w}$, they were milled and ground into a fine or very nice coarse powder $(100 \mathrm{~g})$ using a miller. The dried material of both Oedogonium globosum and Oedogonium intermedium was weighed and the powdered algal sample $(100 \mathrm{~g})$ was put into the extractor $(1000 \mathrm{ml}$ capacity) with solvents $(500 \mathrm{ml}$ each $)$ of increasing polarity viz., chloroform, methanol, and cold water, hot water for a duration of $2 \mathrm{~h}, 3 \mathrm{~h}$ and $4 \mathrm{~h}$ for non-polar, cold-and hot-polar solvents respectively. The contents were shaken at regular intervals and the solvent extract thus obtained was concentrated at $40{ }^{\circ} \mathrm{C}$ to dryness to get a greenish crude product. Extractive values and the yield percentage for all categories were estimated and compared.

\section{Phytochemical screening}

Secondary metabolites presenting in the plants/algal extracts can be identified by a fast, simple, and inexpensive procedure of Phytochemical screening, which can be performed with an active fraction of algae by using the appropriate standard tests [18].

\section{Phytochemical isolation}

From the literature reports [19], it was confirmed that not much research work has been done regarding the bioactive compounds from Oedogonium intermedium. All the three solvent extracts viz., cold-and hot-water extracts and methanol extracts were made dry by suction and keeping in a hot air oven set at $50^{\circ} \mathrm{C}$. They were then mixed with pre-warmed silica and introduced into three separate columns (first one packed with methanolic extract, a second column with hot aqueous and the third one with cold aqueous extract of Oedogonium intermedium), each charged with silica gel, 60-120 mesh (500 g) for chromatographic separation. The columns were eluted with different solvents in order of increasing polarity. The elutes, in serial, had been subjected for the thin-layer chromatographic technique for the identification of the isolated samples through $R_{f}$ value estimation. The fractions, having similar $\mathrm{R}_{\mathrm{f}}$ values, were merged together, evaporated to dryness using rota-vapor, and recrystallized with respective eluting solvents of methanol and distilled water.

\section{Anti-microbial study}

Minimum inhibitory concentration study by disc diffusion mechanism

The sterile impregnated disc, with diluted aqueous and methanolic extracts of algal species at varying quantities $(100,50$ and $25 \mu \mathrm{g} / \mathrm{ml})$, was placed on the agar surface. A loop full of the organisms at $10^{6}$ $\mathrm{cfu} / \mathrm{ml}$ quantity inoculated the incubated plates at $37^{\circ} \mathrm{C}$. The size (diameter) of the inhibition zones was observed and calculated [20].

\section{Zone of inhibition study}

The suspension of the test microorganisms $10 \mu \mathrm{l}\left(10^{6} \mathrm{cells} / \mathrm{ml}\right)$ was applied using a sterilized cotton swab by spread plate method, having the bacterial cultures in Muller Hinton agar media. After solidification, the filter paper discs were impregnated with the test samples of the extracts and placed by sterilizing applicators on test organism plates. Compounds were screened for anti-bacterial activity against Escherichia coli (ATCC. No. 25922), and Staphylococcus aureus (ATCC. No. 51740) using Amikacin $(100 \mu \mathrm{g} / \mathrm{ml})$ as standard and distilled water $(100 \mu \mathrm{g} / \mathrm{ml})$ as control. After incubating the assay plates at 37 ${ }^{\circ} \mathrm{C}$ for $24 \mathrm{~h}$, calculated the width of growth inhibition zones. The determination was performed in triplicate [21].

\section{Wound-healing pharmacological activity}

The wound-healing activity of aqueous extracts of Oedogonium globosum and Oedogonium intermedium was studied by excision wound model, following the international ethical guidelines and under the supervision of the scrutinizing committee of Institutional Animal Ethical Committee (IAEC), Karpagam University (ethical approval No.106, Oct 10, 2011).

\section{Animal selection and acclimatization}

Institutional animal ethical committee approval, reference No. $\mathrm{KU} / \mathrm{IAEC} / \mathrm{Ph}$. D/065 has been obtained for our in vivo experiments. Both male and female Wistar Albino rats (150-200 gm) were purchased from Amrita Institute, Kerala and were maintained in the following manner, in our college animal house for $7 \mathrm{~d}$, housed in polypropylene cages, fed with quality rodent pellet diet, water ad libitum, room temperature $21-25^{\circ} \mathrm{C}$, relative humidity $50-60 \%$ and kept for fasting over night for at least $12 \mathrm{~h}$. Feeding tubes and syringes were used to administer the drug.

\section{Acute dermal irritation test, OECD guidelines 404}

Samples $(2 \mathrm{mg} / \mathrm{kg})$ were prepared in ointment form with olive oil, for dermal application. A standard irritant patch $(0.8 \% \mathrm{w} / \mathrm{v}$ formaldehyde), a control (placebo) patch and test samples of aqueous extracts of Oedogonium globosum-and Oedogonium intermedium-loaded transdermal patches were prepared for the study. An area of approximately $150 \mathrm{~cm}^{2}\left(10 \times 15 \mathrm{~cm}^{2}\right)$ was exposed to aid the scoring by removing the dorsal fur [22].

Test sample $(0.5 \mathrm{ml})$ was applied to a metallic patch with one rat, mounted on a Micropore tape, wrapped around the abdomen and secured by an elastic bandage as an initiation of the study. When once the dressing was removed, no sign of necrosis or corrosion was observed. The same procedure was continued with two samples to separate skin-sites and or with two further animals. Dermal response scores at 1, 24, 42 and $72 \mathrm{~h}$ were evaluated for each animal, then after for the next $7 \mathrm{~d}$ as a further observation. Untreated skin of adjacent areas was treated as a control. The irritation scores of erythema and edema were scored on a scale of $0-4$ and to obtain the primary irritation index; mean scores were averaged.

\section{Excision wound model}

Animals were anesthetized at the time of wound creation. An excision wound of circular area $500 \mathrm{~mm}^{2}$ and $0.2 \mathrm{~cm}$ depth, marked 
with picric acid, was created using toothed forceps, a surgical blade, and pointed scissors after removing the dorsal fur. It was left open after cleaning with normal saline [23].

The animals were divided into four groups $(n=6)$. The group I animals (placebo control) were topically treated with Ointment base I. P., Group II and Group III with the 10\% ointment of the aqueous extract of Oedogonium globosum and Oedogonium intermedium respectively; and Group IV with the $10 \%$ ointment of the standard, Silver sulfadiazine. The treatment procedure, dressing up the wounds with standard and test samples every day, was started immediately after the wound creation for $14 \mathrm{~d}$. The wound closure rate was assessed using a graph paper on days $0,3,5,7$, and 14 post-wounding. The period of epithelialization was done by measuring the $\%$ of reduction in the wound area size at intervals from the next day of treatment.

Wound healing \%

$=\frac{(\text { st day wound spot area }- \text { Specific day wound spotarea }) \text { X } 100}{1 \text { st day wound spot area }}$

\section{Statistical analysis}

The data were applied to one-way ANOVA and Dunnett's multiple comparisons to study the changes; P values significant criteria; Mean of result data by SEM Software: GraphPad Prism 5.01.

\section{RESULTS}

Two species of algae were extracted by cold maceration and hot extraction with distilled water, methanol and, chloroform. Since $O$. intermedium samples were found to be yielding more quantity of extracts (65\%) comparing to 0 . globosum (30\%, owing to dampened nature), we started to continue our research with the former algal species of the three extractions of Oedogonium intermedium, the yield of cold methanolic extract (72\%) was found to be significantly greater than hot methanolic (33\%). Similarly, comparing to the hot aqueous extract ( $61 \%)$, the cold extract $(70 \%)$ was found to be more in yield (table 1). On phytochemical screening, glycans, flavonoids and terpenoids were to be present (table 2). TLC was performed on the extracted materials of algal species.

Table 1: Percentage yields of crude extracts

\begin{tabular}{|c|c|c|c|c|c|c|}
\hline S. No. & Name of the sample & $\begin{array}{l}\text { Quantity of powdered } \\
\text { material (g) }\end{array}$ & Name of the extract & $\begin{array}{l}\text { Amount of } \\
\text { extract (g) }\end{array}$ & $\%$ Yield & $\begin{array}{l}\text { Melting point } \\
\text { in }{ }^{\circ} \mathrm{C}\end{array}$ \\
\hline \multicolumn{7}{|c|}{ Trial extraction } \\
\hline \multirow[t]{3}{*}{1} & Sample-A & 5 & Chloroform & 0.54 & 10.80 & - \\
\hline & (Oedogonium & 5 & Methanol & 1.85 & 37.00 & - \\
\hline & globosum) & 5 & Distilled water & 1.42 & 28.40 & - \\
\hline \multirow[t]{3}{*}{2} & Sample-B & 5 & Chloroform & 2.00 & 40.00 & - \\
\hline & (Oedoonium & 5 & Methanol & 4.25 & 85.00 & - \\
\hline & intermedium) & 5 & Distilled water & 3.30 & 66.00 & - \\
\hline \multicolumn{7}{|c|}{ Bulk extraction of Sample-B (Oedogonium intermedium) } \\
\hline 1 & Samlpe-B & 25 & Hot Methanol & 11.25 & 45.00 & - \\
\hline 2 & (Oedoonium & 25 & Methanol & 22.50 & 90.00 & 210 \\
\hline 3 & intermedium) & 25 & Hot water & 15.425 & 61.70 & 116 \\
\hline 4 & & 25 & Cold water & 21.75 & 87.00 & 67 \\
\hline
\end{tabular}

Table 2: Preliminary phytochemical analysis of the aqueous and methanolic extracts of Oedogonium Intermedium

\begin{tabular}{|c|c|c|c|}
\hline S. No. & Phytoconstituents & AEOI & MEOI \\
\hline 01. & Alkaloids & + & + \\
\hline 02. & Polysaccharides & +++ & +++ \\
\hline 03. & Saponins & - & - \\
\hline 04. & Terpenoids & +++ & +++ \\
\hline 05. & Flavanoids & +++ & +++ \\
\hline 06. & Steroids & + & + \\
\hline 07. & Glycosides & ++ & ++ \\
\hline 08. & Tannins & + & + \\
\hline
\end{tabular}

Where AEOI-Aqueous extract and MEOI-Methanolic extracts of Oedogonium intermedium; +++-highly present; ++-moderately present; +-slightly present and '-' absence of Phyto-constituents.

The various extracts were then separated for individual Phytoconstituents by the varying proportion of methanol and distilled water. When detected in iodine chamber and UV cabinet, single spotted elutes were collected and combined. Three different fractions were in such a manner obtained as pure Phytoconstituents (table 3).

Table 3: Details of the isolated fractions of the Oedogonium intermedium

\begin{tabular}{|c|c|c|c|}
\hline S. No. & Name of the algal extracts & $R_{\mathrm{f}}$ value & Phytoconstituents \\
\hline \multicolumn{4}{|c|}{ Cold Aqueous Extract } \\
\hline 01. & Fractions-1,2,3,4,5,6 & $0.32-0.34$ & Glycans \\
\hline 02. & Fractions-6,7,8,9,10,11 & $0.44-0.48$ & [Phyto-constituent I] \\
\hline \multicolumn{4}{|c|}{ Hot Aqueous extract } \\
\hline 03. & Fractions-1,2,3 & 0.40 & Flavonoids \\
\hline 04. & Fractions $-4,5,6$ & 0.72 & [Phyto-constituent II] \\
\hline \multicolumn{4}{|c|}{ Methanol Extract } \\
\hline 05. & Fractions-1,2,3,4,5,6 & $0.46-0.56$ & Terpenoids \\
\hline 06. & Fractions-6,7,8,9,10,11,12,13,14 & $0.23-0.34$ & [Phyto-constituent III] \\
\hline 07. & Fractions-15,16,17,18,19,20 & 0.77 & \\
\hline
\end{tabular}


Phyto-constituent I, Glycans: was obtained with cold distilled water as the eluent. A variety of glucoside derivatives of both (+) and $(-)$ enantiomers in the form of pure green colored and amorphous powder have been isolated upon re-crystallization. Its TLC study revealed its presence through a single spotting $\left(R_{f}\right.$ value 0.33$)$ in the mobile phase of methanol and distilled water (3:7). A Melting point value is $67^{\circ} \mathrm{C}$. IR spectra were characterized as IR: $3500-2500 \mathrm{~cm}^{-1}$ for $\mathrm{OH}$ stretching; $1600 \mathrm{~cm}^{-1}$ for $\mathrm{C}-\mathrm{C}$ stretching, benzene nucleus; 1320-1210 $\mathrm{cm}^{-1}, \mathrm{C}-\mathrm{O}$ stretching, Aryl; $585 \mathrm{~cm}^{-1}=\mathrm{C}-\mathrm{H}$ bend, medium; The absorption maxima, $\lambda \max$ was recorded as $291 \mathrm{~nm}$ with distilled water as solvent. They were analyzed in the ${ }^{1} \mathrm{HNMR}$ spectrum $\left(\delta \mathrm{ppm}, \mathrm{D}_{2} \mathrm{O}\right)$ presence of four singlets at $\delta_{\mathrm{H}} 1.182(1 \mathrm{H}$, $\left.\mathrm{CH}_{3}, \mathrm{~S}, \mathrm{~J}=16.8 \mathrm{~Hz}\right) 1.224\left(1 \mathrm{H}, \mathrm{CH}_{3}, \mathrm{~d}, \mathrm{~J}=6.4 \mathrm{~Hz}\right), 1.240\left(1 \mathrm{H}, \mathrm{CH}_{3}, \mathrm{~d}\right)$ and $1.813\left(1 \mathrm{H}, \mathrm{CH}_{3}, \mathrm{~S}\right)$ for three protons each were assigned to methyl groups. The sharp singlet observed at $\delta_{\mathrm{H}} 1.183\left(1 \mathrm{H}, \mathrm{CH}_{3}, \mathrm{~S}\right)$ and $8.352(1 \mathrm{H}, \mathrm{COOH}, \mathrm{S})$ were assigned to- $\mathrm{CH}_{3}$ and-COOH groups, respectively. Oxygenated proton afforded a doublet and a double triplet at $\delta_{\mathrm{H}} 3.106(1 \mathrm{H}, \mathrm{OH}, \mathrm{d}, \mathrm{J}=11.5 \mathrm{~Hz})$ and $3.22(1 \mathrm{H}, \mathrm{OH}, \mathrm{dt})$. Other protons were as multiplet, lie in the range of 1.21-2.20. Mass $(\mathrm{m} / \mathrm{z})$ : Base peak value is 90.87 , the molecular ion peak has $\mathrm{m} / \mathrm{z}$ value as 68.94 and the other peaks correspond to ion fragments, whose $\mathrm{m} / \mathrm{z}$ ratios were found to be as 127.77, 154.66 and 184.62 .

Phyto-constituent II, Flavanoids: was obtained with hot distilled water as the eluent. A pure amorphous powder of green coloured isolate had exited upon re-crystallization. $\mathrm{R}_{\mathrm{f}}$ value 0.40 (n-butanol: acetic acid: water in 2:2:6 as mobile phase). A Melting point value $116^{\circ}$ C. IR spectra were characterized as IR: $3500-2500 \mathrm{~cm}^{-1}$ for-OH stretching; $1400 \mathrm{~cm}^{-1} \mathrm{CH}_{2}-\mathrm{C}=0$ stretching; $1130 \mathrm{~cm}^{-1} \mathrm{C}-\mathrm{O}$ stretching. The absorption maxima, $\lambda \max$ was recorded as $290 \mathrm{~nm}$ with distilled water as solvent. In the ${ }^{1} \mathrm{HNMR}$ spectrum $\left(\delta \mathrm{ppm}, \mathrm{D}_{2} \mathrm{O}\right)$ presence of two singlets at $\delta_{\mathrm{H}} 1.240\left(1 \mathrm{H}, \mathrm{CH}_{3}, \mathrm{~S}\right)$ and $1.813(1 \mathrm{H}$, $\mathrm{CH}_{3}$,d) for three protons each was assigned to methyl groups. The sharp singlets observed at $\delta_{\mathrm{H}} 2.174\left(1 \mathrm{H}, \mathrm{CH}_{3}, \mathrm{~S}\right)$ and $7.410(1 \mathrm{H}$,
$\mathrm{COOH}, \mathrm{S}$ ) were assigned to- $\mathrm{CH}_{3}$ and- $\mathrm{COOH}$ groups respectively. Oxygenated proton afforded a doublet and a double triplet at $\delta_{\mathrm{H}}$ $2.295(1 \mathrm{H}, \mathrm{OH}, \mathrm{d}, \mathrm{J}=4.4 \mathrm{~Hz})$ and $3.106(1 \mathrm{H}, \mathrm{OH}, \mathrm{dt})$. Other protons were as multiplets lie in the range of $\delta_{\mathrm{H}}$ 1.240-3.106. A doublet observed at $\delta_{\mathrm{H}} 2.605(2 \mathrm{H}, \mathrm{d})$ was due to the presence of two protons. Mass (m/z): Base peak value is 58.72, the molecular ion peak has $\mathrm{m} / \mathrm{z}$ value as 68.94 and the other peaks correspond to ion fragments, whose $\mathrm{m} / \mathrm{z}$ ratios were found to be as $127.77,149.79$ and 265.78 .

Phyto-constituent III, Terpenoids: was obtained with methanol as the eluent. A pure amorphous powder of green colored isolate had exited upon re-crystallization. Its TLC study revealed its presence through a single spotting $\left(\mathrm{R}_{\mathrm{f}}\right.$ value 0.77$)$ in cyclohexane: acetone (1:1) as mobile phase. Melting point value is $210^{\circ} \mathrm{C}$. IR spectra were characterized as IR: $3500-2500 \mathrm{~cm}^{-1}$ for $\mathrm{OH}$ stretching; 2900-2695 $\mathrm{cm}^{-1} \mathrm{C}-\mathrm{H}$ stretching, aldehydes $1400 \mathrm{~cm}^{-1} \mathrm{CH}_{2}-\mathrm{C}=0$ stretching; 1320 $1210 \mathrm{~cm}^{-1}, \mathrm{C}-\mathrm{O}$ stretching, $1130 \mathrm{~cm}^{-1} \mathrm{C}-0$ stretching. The absorption maxima, $\lambda \max$ was recorded as $301 \mathrm{~nm}$ with distilled water as solvent. In the ${ }^{1} \mathrm{HNMR}$ spectrum $\left(\delta \mathrm{ppm}, \mathrm{D}_{2} \mathrm{O}\right)$ presence of six singlets at $\delta_{\mathrm{H}} 1.082\left(1 \mathrm{H}, \mathrm{CH}_{3}, \mathrm{~S}, \mathrm{~J}=4.3 \mathrm{~Hz}\right), 1.119\left(1 \mathrm{H}, \mathrm{CH}_{3}, \mathrm{~S}, \mathrm{~J}=6.6 \mathrm{~Hz}\right)$, $1.185\left(1 \mathrm{H}, \mathrm{CH}_{3}, \mathrm{~S}\right), 1.819\left(1 \mathrm{H}, \mathrm{CH}_{3}, \mathrm{~S}\right), 1.954\left(1 \mathrm{H}, \mathrm{CH}_{3}, \mathrm{~S}\right)$ and 2.089 $\left(1 \mathrm{H}, \mathrm{CH}_{3}, \mathrm{~S}\right)$ for three protons each were assigned to methyl groups. The sharp singlets observed at $\delta_{\mathrm{H}} 1.819\left(1 \mathrm{H}, \mathrm{CH}_{3}, \mathrm{~S}\right), 4.676(1 \mathrm{H}$, $\mathrm{COOH}, \mathrm{S})$ and $4.701(1 \mathrm{H}, \mathrm{S})$ were assigned to- $\mathrm{CH}_{3}$ and-COOH groups, respectively. Oxygenated proton afforded a doublet and a double triplet at $\delta_{\mathrm{H}} 2.295\left(1 \mathrm{H}, \mathrm{CH}_{3}, \mathrm{~d}, \mathrm{~J}=7.1 \mathrm{~Hz}\right)$ and $3.106(1 \mathrm{H}$, $\mathrm{CH}_{3}, \mathrm{dt}$ ). Other protons were as multiplets lie in the range of $\delta_{\mathrm{H}}$ $0.760-3.666$. The doublets observed at $\delta_{\mathrm{H}} 1.989(2 \mathrm{H}, \mathrm{d})$ and 2.809 $(2 \mathrm{H}, \mathrm{d})$ were due to the presence of two protons. Mass $(\mathrm{m} / \mathrm{z})$ : Base peak value is 60.57 , the molecular ion peak has $\mathrm{m} / \mathrm{z}$ value as 68.94 and the other peaks correspond to ion fragments, whose $\mathrm{m} / \mathrm{z}$ ratios were found to be as $82.97,90.88$ and 149.69 .

Table 4: Anti-bacterial activity of freshwater algal species $(10 \mu \mathrm{g} / 10 \mu \mathrm{l} / \mathrm{disc})$, Amikacin $(1 \mu \mathrm{g} / 10 \mu \mathrm{l} / \mathrm{disc})$ by disc diffusion method

\begin{tabular}{llll}
\hline S. No. & Name of the algal extracts & Zone of inhibition (mm) & \multicolumn{1}{c}{ Staphyloccocus aureus } \\
\cline { 3 - 4 } & & Escherchia coli & $49+0.25$ \\
\hline 01. & Amikacin & $61+1.21$ & $31+0.49$ \\
02. & Oedogonium globosum & $19+0.41$ & $42+0.87$ \\
03. & Oedogonium intermedium & $22+1.02$ & \\
\hline
\end{tabular}

Values represent the mean $+\mathrm{SD}$; number of readings in each group $=3$

Table 5: Data acquired in the acute dermal irritation test

\begin{tabular}{|c|c|c|c|c|c|c|c|c|c|c|c|c|c|}
\hline \multirow[t]{3}{*}{ Group } & \multirow[t]{3}{*}{ Treatment } & \multicolumn{12}{|c|}{ Observation: skin irritation scores } \\
\hline & & \multicolumn{2}{|c|}{ Immediately (3 Sec) } & \multicolumn{2}{|c|}{ 1h } & \multicolumn{2}{|c|}{$24 h$} & \multicolumn{2}{|c|}{$48 \mathrm{~h}$} & \multicolumn{2}{|c|}{$72 \mathrm{~h}$} & \multicolumn{2}{|c|}{ 7D } \\
\hline & & $\mathbf{A}$ & B & $\mathbf{A}$ & B & $\mathbf{A}$ & B & $\mathbf{A}$ & B & $\mathbf{A}$ & B & $\mathbf{A}$ & $\mathbf{B}$ \\
\hline Control & No medication & NA & 0 & 2 & 1 & 0 & 1 & 0 & 1 & 0 & 0 & 0 & 0 \\
\hline Test 1 & Sample A (O. globosum) & NA & 0 & 2 & 1 & 2 & 0 & 0 & 0 & 0 & 0 & 0 & 0 \\
\hline Test 2 & Sample B (O. intermedium) & NA & 0 & 2 & 1 & 0 & 0 & 0 & 0 & 0 & 0 & 0 & 0 \\
\hline
\end{tabular}

Well-defined erythema and very slight oedema have resulted in the treated skin-areas of the three rats, when exposed to $0.5 \mathrm{ml}$ of test solutions (Oedogonium globosum and Oedogonium intermedium) for four hours. The skin irritation had resolved within 7 days and no evidence of either a corrosive effect or systemic toxicity symptoms and or any mortality (table 5). Anti-oxidant activity, anti-cancer and antidiabetic activities may be expected owing to polyphenolic compounds and astringent and anti-microbial properties owing to flavonoids. The current research's results showed good wound closing responses which might be due to enhanced formation of granulated tissues, collagen, skin appendages and re-epithelialization. The algal extracts should have stimulated the endogenous antioxidants and thus protected the tissues from free radical-mediated damages.

Excision wound healing by contraction and epithelialization model was followed to assess the percentage of wound closure or closure rate study. Wound healing study data of the sponges has been shown in (table 6). Silver sulfadiazine showed more potent significant wound breaking strength compare to that of control group rats. Comparing to the control, all test samples showed a diminish in the area of the cut wounds on the $14^{\text {th }}$ day $(\mathrm{P}<0.05)$. On the third and sixth days, the wound healing effect of the standard (46\% and $65 \%$ respectively) was significant $(\mathrm{P}<0.05)$. The rate of wound closure of the test samples O. globosum (42\%) and 0 . intermedium (47\%) were found to be almost equal to that of the standard from $9^{\text {th }}$ day of observation. 
Fig. 2: Percentage wound amelioration of the methanolic extract of Oedogonium species

Table 6: Percentage wound amelioration of the methanolic algal extracts

\begin{tabular}{|c|c|c|c|c|c|}
\hline \multirow[t]{2}{*}{ Group } & \multirow{2}{*}{$\begin{array}{l}\text { Dose level } \\
\text { (mg/kg) }\end{array}$} & \multicolumn{4}{|c|}{ \% Wound Healing in different days in sq. $\mathrm{mm}$} \\
\hline & & Day-03 & Day-06 & Day-09 & Day-15 \\
\hline Control & - & $12.98 \pm 0.320$ & $14.82 \pm 0.2414$ & $23.32 \pm 1.061$ & $33.32 \pm 1.061$ \\
\hline Standard & 20 & $46.51 \pm 1.018^{* * *}$ & $64.84 \pm 1.218^{* * *}$ & $69.84 \pm 2.763^{* * *}$ & $94.84 \pm 1.218^{* * *}$ \\
\hline Oedogonium globosum & 20 & $20.04 \pm 0.2430^{*}$ & $30.54 \pm 0.2430^{* *}$ & $42.21 \pm 1.429^{* * *}$ & $72.21 \pm 1.429^{* * *}$ \\
\hline Oedogonium intermediums & 20 & $16.75 \pm 0.0768^{*}$ & $25.25 \pm 1.451^{* *}$ & $46.92 \pm 0.224^{* * *}$ & $86.92 \pm 0.2242^{* * *}$ \\
\hline
\end{tabular}

All values are by Mean $\pm \mathrm{SD}(\mathrm{n}=3)$. ${ }^{* * *} \mathrm{P}<0.001,{ }^{* *} \mathrm{P}<0.01$ and ${ }^{*} \mathrm{P}<0.05$, as compared to control. One-way ANOVA followed by Turkey's post hoc multiple comparison tests.

\section{DISCUSSION}

Worldwide diseases' responsible, foodborne pathogens, though show resistance against contemporary antibiotics, found to be controlled by more eco-friendly, natural products, being found in consumers' diets i.e. seaweeds [26]. Two species of algae were extracted by cold maceration and hot extraction with distilled water, methanol and, chloroform. In anti-bacterial study, 0 . intermedium was showing a comparatively higher inhibition effect than O. globosum. However, these algal species were found to be significant in action only against the gram-positive bacteria because of the complex structure of gramnegative bacteria [27-29]. Though the data supports for the less inhibitory action of the tested species, but was observed that E. Coli and $S$. aureus organisms responded to the actions of algal isolations. The prevalence of anti-microbial chemical defense effects, effectively observed in the seaweeds [30], may be due to the presence of chemical compounds like terpenes, acetogenins, indoles, phenols, fatty acids, halogenated hydrocarbons [31-32].

The inherent wound healing property of algae were going high in value of wound healing property in all $14 \mathrm{~d}$ observation and the effect of 0 . intermedium (87\%) at par to the standard (95\%) in action and significantly greater than the other 0 . globosum $(72 \%$, $\mathrm{P}<0.05)$. From literature, it was observed that the wound healing activity of seaweeds might be due to the proliferation of cells, collagen, granulation tissue formation [33]. Hydroxylated cinnamic acid, phosphotidyl serine isomeric derivatives and sulfoquinovosyl diacylglycerol [34-35] are the chemical constituents being found in algal species, might be responsible for the proliferation and migration of keratinocytes and fibroplasts. These findings thus help us, the researcher, to proceed further with the later species for other related pharmacological evaluation like anti-coagulant or anticancer activities in the future.

\section{CONCLUSION}

Thus, this current work adds to the reliability of this natural molecule as a good candidate for medical use in the future in Indian folk medicine. Until recently, there was a lack of reports on phytochemical composition and other parts of either pharmacological actions or standardization data or Physico-chemical properties details. Though the algal species are, in general, quite promising for further work in this regard, yet research can be keenly focused in the following aspects: i) In addition to extraction, the structure of the identified bioactive compounds, in the future, to be elucidated using other spectroscopic determinations ii) Vast experimental data should be retrieved from traditional medicines. iii) Modern scientific validation and standardization methods can be encouraged to obtain a significant market value of these marine species.

\section{ACKNOWLEDGEMENT}

The research manuscript writers express their gratitude to Karpagam College of Pharmacy, Coimbatore-641032, Tamil Nadu, India and The TN Dr. MGR Medical University, Chennai for providing the facilities to accomplish this research work successfully.

\section{FUNDING}

Nil

\section{AUTHORS CONTRIBUTIONS}

M. Karpakavalli originated the research work and wrote the manuscript; A. Y. Sangilimuthu made suggestive revision; G. Prakash, P. Sivasubramaniam and D. Renjithkumar developed the document; finally S. Mohan has corrected the manuscript and approved the final version. This research did not receive any specific grant from funding agencies in the public, commercial, or not-for-profit sectors.

\section{CONFLICTING OF INTERESTS}

Nil

\section{REFERENCES}

1. Rajasulochana P, Preethy V. Glimpses on cosmetic application using marine red algae. Res Int J Pharm Tech 2015;7:9235-42.

2. Mariana NS, Neela VK, Nik Kani MA, Norfarrah S, Zamberi S. In vivo evaluation on Malaysian coastel isolates of Gracilaria changii and Stichopus badionotus through heat-burn methicillin resistant Staphylococcus aureus (MRSA) infection animal model. Res Afr J Microbiol 2011;5:1379-82.

3. Adithya T, Bitu M, Eleanor. The role of algae in pharmaceutical development. Res J Pharm Nanotech 2016;4:82-89.

4. Lavanya R, Fazina M, Kajal C, Lokanatha V. Phytochemical evaluation and antimicrobial activity of Gracilaria Opuntia: an important anti-diabetic red marine macroalgae. Int J Curr Pharm Res 2017;9:37-41.

5. Shyamala V, Ebciba, Santhiya N, Thangaraju. Phytochemical screening and In vitro antibacterial, antioxidant and anticancer activity of Amphiroa fragilissima (Linneaus) V, Lanmoroux. Res Int J Innov Res Sci 2014;3:12933-48.

6. Harsha KD, Joshi D, Preeti P, Manish KP, Amit CK. Algae as future drug. Res Asian J Pharm Clin Res 2012;5:1-4.

7. Devaraj ID, Paramasivam G, Rajalakshmi J, Solomon J. Antioxidant activities of marine algae Valoniopsis pachynema and Sargassum swartzii from the southeast coast of India. Int J Fisher Aqua Stud 2015;3:426-30.

8. Seenivasan R, Archana G, Geetha S, Indu H. The antibacterial and anti-oxidant activity of some marine algae from the south east coast of India. Res American-Eurasian J Agric Environ Sci 2010;9:480-9.

9. Sujatha L, Subba RG, Lalitha GT. Antibacterial activity of green seaweeds on oral bacteria. Nat Prod 2012;3:328-33.

10. Rabia A, Salah A, Fauzi W, Abduel R, Fatiem G. Screening of antibacterial activity in marine green, red and brown macro algae from the western coast of libya. Nat Sci 2013;5:7-14.

11. Stephen S, Timothy J, Entwisle. New taxa and combinations for Oedogonium and bulbochaete odeogoniales,chlorophyceae) in Australia, Telopea 2006;11:171-94.

12. Santhanam S, Aseer M, Sugathan S, Joseph, George S. Antibacterial activity of seaweeds extracts against multiresistant pathogens. Ann Microbiol 2008;58:535-41.

13. Fedekar F, Madkour MH, Mohsen K, Waleed S, Walied. Wound healing activity of brown algae plus polyherbal extract in normal and alloxan-induced diabetic rats. Res J Adv Vet 2013;3:102-8.

14. Kumara SHM, Krishna V, Shankarmurthy K, Abdul RB, Mankani $\mathrm{KL}$, Mahadevan KM. Wound healing activity of embelin isolated from the ethanol extract of leaves of Embelia ribes Burm. J Ethnopharmacol 2007;109:529-34. 
15. Izabela M. Algal extracts technology and advances. English Life Sci 2014;14:581-91.

16. Sarah S, Abdu-llah Al-S, Nevein A, Hend A, Wazanani AA, Ibrahim AA. Antibacterial substances from marine algae isolated from Jeddah coast of red sea, Saudi Arabia. Saudi J Biol Sci 2014;24:57-64.

17. Lokesh R, Manasvi V, Praveena LB. Antibacterial and antioxidant activity of saponin from Abutilon Indicum leaves. Asian J Pharm Clin Res 2016;9:344-7.

18. Dalia F, Muhammad El-Saadani. Phytochemical constituents and bio-screening activities of green algae (Ulva lactuca). Res Int J Agric Policy 2014;2:373-8.

19. Radhika D, Mohaideen A. Study on Immunostimulatory property of few Seaweeds injected intraperitoneally. Int J Curr Pharm Res 2017;9:135-9.

20. Bimala S, Tank Raj S, Ram Chandra K, Ganga Prasad P. Assessment of antimicrobial and antioxidant activities of Amomum Subulatum roxb. of Nepal. Asian J Pharm Clin Res 2017;10:95-7.

21. Santhanam S, Aseer M, Sugathan S, Joseph S, George S. Antibacterial activity of seaweeds extracts against multiresistant pathogens. Ann Microbiol 2008;58:535-41.

22. Shimaa M, Shafay EI, Samh Ali M, Mostafa, EI-Sheekh. Antibacterial activity of some seaweed species from red sea, against multidrug-resistant bacteria. Egyptian J Aqua Res 2016; 42:65-74.

23. Panigrahi BB, Panda PK, Patro VJ. Wound healing activity of Spirulina extracts. Res Int J Pharm Sci 2011;6:132-5.

24. Prashanthkumar P, Angadi BS, Vidyasagar GM. Antimicrobial and anti-inflammatory activity of blue-green algae. Res Indian J Pharm Sci 2006;68:647-8.

25. Turkiyede Y, Bazi C, Otlarinin Y, Iyilestirici E. Wound healing potential of selected liverworts growing in turkey. Res Turkish J Pharm Sci 2016;13:285-91.
26. Lucy M, Premalatapati R, Panigrahy, Subrat KB. Therapeutic health booster seaweeds against several maladies. Indian J Geo-Marine Sci 2013;42:538-46.

27. Fedekar F, Madkour, Mohsen MH, Waleed K, Walied S. Wound healing activity of brown algae plus polyherbal extract in normal and alloxan-induced diabetic rats. Res J Adv Vet 2013;3:102-8.

28. Sasidharan Y, Chen D, Saravanan KM, Sundram L, Yoga L. Extraction, isolation and characterization of bioactive compounds from plants' extracts. Afr J Tradit Complementary Altern Med 2011;8:1-10.

29. Sarwono AT, Suniarti DF. Roselle Calyx ethanol extract stimulates oral mucosal wound healing. Int J Appl Pharm 2017;9(Suppl 2). DOI:10.22159/ijap.2017.v9s2.10

30. Arif B, Risris K, Tazyinul QA. Wound-healing test of Piper Betle leaf extract and Aloe Vera in gel preparation. Int J Appl Pharm 2018;10:86-91.

31. Karodi R, Jadhav M, Rub R, Bafna A. Evaluation of the wound healing activity of a crude extract of Rubia cordifolia L. (Indian madder) in mice. Int J Appl Res Nat Prod 2009;2:12-8.

32. Ashoka BVL, Goravanakolla A, Murali A, Madhava V, Yoganarasimhan SN. Wound healing activity of the leaves of Wattakaka volubilis (L. f.) Stapf (Asclepiadaceae). Int J Appl Res Nat Prod 2012;5:23-9.

33. Seung HH, Jai MJ, Soon SL. Isolation of fucosterol from Pelvetiasi liquosa by high-speed counter-current chromatography. Fish Aqua Sci 2012;15:191-5.

34. Xiao HX, Zhi QY, Gong KL. Preparation of phytosterols and phytol from edible marine algae by microwave-assisted extraction and high-speed counter-current chromatography. Res Sepn Purif Tech 2012;104:284-9.

35. David L, Ballantine G, Pablo H, William, Gerwick M, Sylvia E, et al. Antibiotic activity of lipid-soluble extracts from caribbean marine algae. Hydrobiol 1987;151:463-9. 